SMART Journal, Volume 6, No. 2, August 2020, Page 118- 126

ISSN Cetak : :2356-2048

ISSN Online : :2356-203X

\title{
STUDENTS' MOTIVATION IN WRITING AT LESSON STUDY
}

\author{
Maya Mutiara Putri ${ }^{1)}$, Rahmatika Kayyis ${ }^{2)}$, Kurniati ${ }^{3)}$, Fitri Wulandari ${ }^{4)}$, \\ Renita Sugesti ${ }^{5}$. \\ 1) 2) 3) 4) English Education Department of FKIP UMPRI \\ Email Correspondence: mayamutiarap@gmail.com
}

\begin{abstract}
This research was a collaborative action research that was aimed to increase the students' motivation in writing by Lesson Study at VIII B Ikhwan of SMP IT Insan Mulia Pringsewu, Lampung. There were two cycles in this study. The result of this research presented that Lesson Study gave impact in increasing the students' motivation; the intrinsic and extrinsic motivation. These aspects influenced and supported each other. After the implementation amount of the students who had good willingness in learning increased becoming more than part of them. Lesson study gave the good impact for both the students and the model teacher.
\end{abstract}

Keywords: Lesson study, extrinsic, intrinsic motivation, writing

\section{INTRODUCTION}

According to Lesson Study team in Hasanuddin et al (2018) ,Lesson Study is chosen because the development of learning media depends on the result sharing of professional knowledge based on the practice and result and also can increase professional competences and pedagogics of the teachers. Susilo et al (2011) states the implementation of Lesson Study can increase science process creativity, motivation and the students score in their research. Lesson study is actually a learning forum to learn each other from the other experiences to improve the teaching-learning quality. Because lesson study is a source of real examples of how to do learning, participation as an observer in lesson study or observing lesson study directly can be used to improve the quality of the learning-teaching process. Lesson Study can be used for all subjects in the curriculum including English.

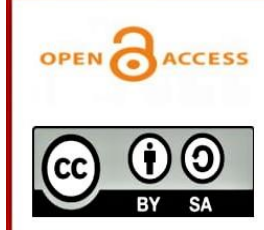

Creation is distributed under the Creative Commons License Attribution Share Alike 4.0 International Published in https://ejournal.umpri.ac.id/index.php/smart/index

SMART Journal: Journal of English Language Teaching and Applied Linguistics 
The researcher observed the students of VIII B Ikhwan of SMP IT Insan Mulia Pringsewu who have a heterogeneous English skills. As the students of boarding school, theyhad a lot of activity not only in the classroom but also in their dormitory. Because of that, their motivation in the classroom got up and down.

For their writing skill, they only could copy what they saw in their handbook. It was difficult for them to arrange the sentences to make a text. Richards and Renandya (2002: 303) in Purnama (2016) state that there is no doubt that writing is the most difficult skill for second language learners to master. Although writing is the most difficult skill if the students have high motivation, it can help students in learning-teaching process. Rosalina (2014) states that motivation is one of the important things in learning process and it can help someone achieve his or her goals if they have strong motivation in doing steps to achieve it. Therefore, the main focus of the implementation of lesson study was the students' motivation in writing during the activities of learning-teaching process. There were some related studies. The first was conducted by Setiawan (2018) "The Implementation of Quantum Teaching (QT) and Think Talk Write (TTW) through Lesson Study to Improve Students' Learning Motivation". The research was intended to improve students' learning motivation at studying and learning course for fifth semester of Biology Education. The students were given the opportunity to be active in playing a role in learning, either in answering questions of model lecturer, answering or giving questions during the discussion, and taking an active role in concluding the lesson. The second was Aimah (2016) "Lesson Study: A Way To Enhance Students' Motivation In Learning Process In The Classroom”. This study investigated whether lesson study can enhance the students' motivation in English Education Study Program of Semarang State University in Language Testing Administration (LTA) class. Aimah (2016) states that 
through lesson study, it enabled lecturer to interact intensively what kind of the problems faced by the students in the classroom. Besides that, the lecturer also could find out the strategy used in the process of teaching learning. Lesson study also enabled to discuss, and shared the knowledge-based experience that the observers had so that the problems could be solved including about students' motivation.

The researcher used Lesson Study to find the problems were faced that influenced the students' motivation in the classroom during the teachinglearning process as well to increase the students' motivation specially in writing skill.

\section{RESEARCH METHOD}

This research was Collaborative Action Research. Sudaryono (2019;662) states the method of action research can be carried out using the mix method concurrent embedded model, by using qualitative as the primer data and quantitative as the secondary data or vice versa. So that, the method was chosen mixed method concurrent embedded model by using qualitative as the primer data and quantitative as the secondary data. The qualitative data was collected in the form of the observation sheet, reflection sheet, interview result, questionnaire and documentation by taking the videos and photos. The quantitative data as the supporting the primer data was collected in from the mean of the students' score that was taken during the implementation by the teacher assessment. This research was conducted with two cycles, Cycle I and Cycle II.

The research procedure of lesson study implementation is similar as the CAR cycles (Kemmis \& McTaggart, 2014:23). Lesson study was carried out by combining the CAR cycles, namely: (1) planning stage, where the model teacher, colleague teacher, expert researchers, and the researcher planned the 
action needed. In Lesson Study called making Chapter Design; (2) doing stage, where the model teacher administered teaching-learning activity based on what had been planned in planning stage and was observed by the other observers. In Lesson Study called Open Class; and (3) seeing stage, where the model teacher and all observers had reflection and evaluation on the teachinglearning process that had been done.

The analysis data technique in this study used Miles and Huberman (1994) that is cited Sugiyono (2014: 247-252) which is involving three steps: reduction data, displaying data, and conclusion drawing/verification.

\section{FINDINGS AND DISCUSSION}

According to Lewis (2002) he mentions that lesson study is an approach that is done in order to improve the teaching learning process. The improvement here is done collaboratively by the teachers/lecturers. Hendayana (2006) cited in Sadia (2008) states that Lesson study is a collaborative and sustainable learning based on the principles of collegiality and mutual learning to build up a learning community. In this research, Lesson Study was implemented by some observers; colleague teacher, students university as well the lecturers and it could increase the students' motivation both from the intrinsic and extrinsic motivation. This aspect influenced and supported each other. The researcher provides the analysis of the findings obtained in the first and second cycle. Those findings would be analyzed as follows:

\section{a. Students' Enthusiasm}

By the research data result, it could be concluded that the students' enthusiasm increased step by step and always there was an improvement in each open class. Stand on the result data, the aspects that role in increasing the students' motivation were getting reward, doing the task that having close correlation of them, and how the students' learning model. In each cycle, the 
model teacher said "I'll give reward if you can....", or "there will be something for you if you can....”. This aspect can boost their enthusiastic to take the teacher challenge (the task). In making greeting card itself, the theme that was given to them about their friends who got medals that was why they were enthusiastic to make greeting card. Then, based on the observation result was found that they had high mobility. It could be summed up if their learning model was kinesthetic. Because of that, all observers decided to give kinesthetic game as a brainstorming and moving their seats to the corner in order to facilitate their learning model during the teaching learning process and producing their greeting card.

\section{b. Students' Confidence Level in Doing the Task}

From the questionnaire data, found that the most of students did not understand what the material had just been explained, how to write and to develop their ideas, also what the vocabulary used in doing the task from the teacher. Because of that, they preferred to work in group in order to be able ask their friends in group than to do individual task. In the cycle 1, found that only $20 \%$ students who had high confidence level to do their task without any help. It meant that there was $80 \%$ students who had the contrary condition. But in the cycle 2, the questionnaire data showed that the students who had high confidence level in doing the task by themselves became $60 \%$ students. It could be concluded that there was an improvement from the cycle 1 to the cycle 2. Based on the data, it was happened because they could comprehend the material well.

\section{c. Students' Comprehending}

In the learning-teaching process, finishing the task from the teacher depends on the students' motivation and comprehending. Such as in the result data, in the first open class only one group that presented their discussion result whereas the teacher instructed all group had to present their discussion 
result. Based on the observation result, the students did not understand well what had been taught. In the second open class, the teacher instructed to make only greeting card outline, but there were some groups made a greeting card indeed. It was because they had understood more than in the last meeting. In the last open class, they could make the greeting card, mention its kind and its part. To sum up, they could follow the teacher instruction and do the task on time if they had understood well what was taught.

\section{d. Students' Teamwork}

In this research, found that there was a role as the peer tutor. In the red group, there were 4 students. During the discussion stage in the first open class, 2 students helped 2 others by re-explaining what the teacher said in order their friend in group could understand to the task was given. It did not find to the other groups, but in the next open class, the 3 other groups started having good teamwork. And it developed till the last open class. Moreover based on the result data, in the last open class all students tried to be active in their own group. The teacher succeeded to create comfortable atmosphere so that the students had the desire to involve in the teaching-learning process. The students' comprehending depended how the teacher delivered the material that influenced to students' teamwork.

Based on the data, the students' teamwork increased because the students' comprehending also increased. This was the extrinsic motivation that influenced to the students' intrinsic motivation. In the beginning of the implementation, only few students who had the good willingness in learning, but after the implementation amount of the students who had good willingness in learning increased becoming more than part of them. The students' confidence level in doing the task was one of the proof that they had good enough of the intrinsic motivation. Because each problem of each open class was analyzed in reflection stage and solved with the other observers. In the 
learning process, when someone could not solve a problem for himself/herself, the other's help would be an important factor to lead a comfortable and valuable situation which might proceed to successful learning that was why in lesson study was needed some people as the observers. The researcher also had the other observation data from the other observers to avoid subjective conclusion. That was the one of the reason that Lesson study enabled to collaboratively discuss the problems of teaching learning process in the classroom. The use of the appropriate strategy in the teaching learning process determined the success of it. The success of teaching learning process also determined the students' study result and positive response in joining the class.

\section{CONCLUSION}

The purpose that had been mentioned in the beginning had been reached stand on the research data. Lesson Study can increase the students' motivation in writing. The students' motivation increased step by step in each open class in both aspects. From the observation data, the students confidence level in doing the task, students comprehending, students' enthusiasm, as well students teamwork were higher than in the beginning of this research. They also wanted to follow the classroom activities although in the beginning only part of them who were active in the classroom. But in the last open class, all students tried to be active in the learning and teaching process moreover the students who did not attend in the other open classes. The students' motivation in writing skill could improve also. They could produce the greeting card by themselves and liked the writing activity in creating their own greeting cards. Lesson study had made the learning-teaching process more structural because although the teacher had planned in the lesson plan, but sometimes it ran unstructured because of the students' condition. Therefore , the teacher lost her purpose of the lesson plan. According to Kurniati \& Wulandari (2019) by peer 
tutor, it can make the process of learning to be organized, and can be exploiting an critical idea which can be poured in making the chapter design and the learning process. That is why Lesson Study could be an alternative approach in teaching English and could be used for the other problems in teaching-learning process including about the students' motivation.

\section{REFERENCES}

Aimah, et al. (2016). Lesson Study: A Way To Enhance Students' Motivation In Learning Process in the Classroom. Semarang: UNNES.

Hasanudin, et al. (2018). Pengaruh Implementasi Perangkat Pembelajaran Berbasis Lesson Study terhadap Peningkatan Keterampilan Proses Sains dan Motivasi Belajar Peserta Didik. Jurnal Biologi Edukasi. Vol 10 (21). : 27-34.

Hendayana, Sumar, et al. (2006). Lesson Study, Suatu Strategi untuk Meningkatkan Keprofesionalan Pendidik (Pengalaman IMSTEP-JICA). Bandung: UPI Press.

Kemmis, S., \& McTaggart, R. (2014). The Action Research Planner. Victoria: Deakin University Press.

Kurniati \& Wulandari. (2019). Peer Tutor in Lesson Study. Jurnal SMART. Vol. 5(2): 108- 118.

Lewis, C. (2002). Does lesson study have a future in the United States. Nagoya Journal of the Education and Human Development. Vol. (1): 1-23.

Purnama, K.D. (2016). Improving Students' Writing Ability Through The Use of Cue Card At Grade Eight of SMPN 4 Yogyakarta Thesis .Yogyakarta: UNY.

Rosalina, V. (2014). The Relationship Between Students' Motivation And Their English Learning Achievement (Thesis). Jakarta : UIN Syarif Hidayatullah.

Setiawan \& Indriwati. (2018). The Implementation of Quantum Teaching (QT) and Think Talk Write (TTW) through Lesson Study to Improve Students' 
Learning Motivation. Scientiae Educatia: Jurnal Pendidikan Sains . 7(1): 79-92.

Sudaryono. (2019). Metodologi Penelitian Kuantitatif, Kualitatif, dan Mix Method ( $2^{\text {nd }}$ Ed). Depok: Rajawali Pers.

Sugiyono. 2014. Metode Penelitian Kuantitatif, Kualitatif dan R\&D. Bandung : Penerbit Alfabeta.

Susilo, H, Chotimah, H, Joharmawan, R, Jumiati, Dwita sari, Y, dan Sunarjo. (2011). Lesson Study Berbasis Sekolah. Malang: Bayumedia Publising. 